Article

\title{
Neuroprotective Effects of Aged Garlic Extract on Cognitive Dysfunction and Neuroinflammation Induced by $\beta$-Amyloid in Rats
}

\author{
Nutchareeporn Nillert ${ }^{1,2}$, Wanassanun Pannangrong ${ }^{1,2}$, Jariya Umka Welbat ${ }^{1,2,3}$, \\ Wunnee Chaijaroonkhanarak ${ }^{1}$, Kittisak Sripanidkulchai ${ }^{1,2}$ and Bungorn Sripanidkulchai ${ }^{2, *}$ \\ 1 Department of Anatomy, Faculty of Medicine, Khon Kaen University, Khon Kaen 40002, Thailand; \\ nutchareeporn16@gmail.com (N.N.); wankun@kku.ac.th (W.P.); jariya@kku.ac.th (J.U.W.); \\ cwunnee@kku.ac.th (W.C.); skitti@kku.ac.th (K.S.) \\ 2 Center for Research and Development of Herbal Health Products, Khon Kaen University, \\ Khon Kaen 40002, Thailand \\ 3 Neuroscience Research and Development Group, Khon Kaen University, Khon Kaen 40002, Thailand \\ * Correspondence: bungorn@kku.ac.th; Tel.: +66-43-202-378
}

Received: 29 October 2016; Accepted: 26 December 2016; Published: 3 January 2017

\begin{abstract}
Neuroinflammation is pathological evidence of Alzheimer's disease (AD) that likely starts as a host defense response to the damaging effects of the $\beta$-amyloid $(A \beta)$ deposits in the brain. The activation of microglia may promote the neurodegenerative process through the release of proinflammatory cytokines, such as interleukin-1 $\beta$ (IL-1 $\beta)$ and tumor necrosis factor- $\alpha$ (TNF $\alpha)$, which may lead to neuronal damage and eventual death. Aged garlic extract (AGE) has been reported to have multiple biological activities, including anti-inflammatory effects. Therefore, the objective of this study was to investigate the effect of AGE on A $\beta$ (1-42)-induced cognitive dysfunction and neuroinflammation. Adult male Wistar rats were given AGE $(125,250$, and $500 \mathrm{mg} / \mathrm{kg}$ BW, body weight), orally administered, daily for 56 days. They were then injected with $1 \mu \mathrm{L}$ of aggregated $A \beta$ (1-42) into the lateral ventricles; bilaterally. Seven days later, their recognition memory was evaluated using a novel object recognition (NOR) test. Then the rats were sacrificed to investigate the alteration of microglia cells, IL-1 $\beta$ and TNF $\alpha$ in the cerebral cortex and hippocampus. The results indicated that AGE at doses of 250 and $500 \mathrm{mg} / \mathrm{kg}$ BW significantly improved short-term recognition memory in cognitively impaired rats. In addition, AGE significantly minimized the inflammatory response by reducing the activation of microglia and IL- $1 \beta$ to the levels found in the control, which is similar to the results found in Celebrex-treated rats. In conclusion, AGE may be useful for improving the short-term recognition memory and relieve the neuroinflammation in $A \beta$-induced rats.
\end{abstract}

Keywords: aged garlic extract; Alzheimer's disease; $\beta$-amyloid; neuroinflammation; neuroprotection; object recognition

\section{Introduction}

Alzheimer's disease (AD) is the most common form of dementia. It is clinically diagnosed using the following criteria: progressive loss of cognition and memory, alterations of personality, and decreasing visual skills [1]. $\beta$-amyloid $(A \beta)$ formation in vulnerable brain regions, such as the hippocampus and cerebral cortex, is a major neuropathological feature of AD [2,3]. It is believed that the deposition of $A \beta$ triggers a series of inflammatory processes, which likely start as a host defense response to the damaging of tissue, and later contributes to neuronal degeneration $[2,4]$. The activation of microglia may promote the neurodegenerative process through the release of proinflammatory cytokines, such as interleukin-1 $\beta$ (IL-1 $\beta$ ) and tumor necrosis factor- $\alpha$ (TNF $\alpha)$ [5-7], and other toxic products [8], which may lead to neuronal cell damage and eventual death. Furthermore, 
these inflammatory mediators present in AD lesions are thought to stimulate the key events of the pathological cascade that result in an increase of $A \beta$ production, which includes the recruitmentand activation of microglia cells [9]. A current treatment for $\mathrm{AD}$ is aimed at reducing amyloid formation by restoring cholinergic deficits with the use of cholinesterase inhibitors (e.g., Donepezil and Rivastigmine) and by regulating neuroinflammation with the use of COX-2 inhibitors (e.g., Celebrex) and non-steroidal anti-inflammatory drugs (NSAIDs, e.g., ibuprofen and indomethacin). However, most of these drugs can cause various side effects such as liver and renal toxicity, gastro-intestinal bleeding, and nausea. In this respect, natural herbal sources with the least amount of adverse effects may provide greater therapeutic benefit in terms of reduction or prevention of neuroinflammation. They could, thus, be beneficial in the treatment of neurodegenerative diseases, including AD. Garlic (Allium sativum) has been recognized for its medicinal value. For this study, fresh garlic was aged over a prolonged period of time in order to create aged garlic extract (AGE). AGE produces a rich content of stable organosulfur compounds such as S-allyl cysteine (SAC) [10], and many other thiosulfinates that are known to exert multiple benefits, e.g., anti-oxidant, anti-inflammatory, and anti-apoptotic effects [11]. Over 350 scientific studies have shown that AGE is safe and effective in providing health benefits in humans [12]. Its neuroprotective effect has also been evaluated in an animal model [13]. AGE has the potential to protect the brain against neurodegenerative conditions [14-18] by preventing brain injury following ischemia [18], protecting neuronal cells against apoptosis [14,17,19], and preventing $\beta$-amyloid-induced oxidative death $[15,16]$. Moreover, treatment with AGE or S-allyl cysteine has been shown to prevent the degeneration of the brain's frontal lobe, improve learning and memory retention, and extend lifespan $[20,21]$. However its anti-inflammatory effect against $\beta$-amyloid-induced toxicity in rats has not yet been investigated. Therefore, the present study used various doses of AGE to demonstrate its beneficial effects on memory performance and against the neuronal toxicity in the hippocampus after $\mathrm{A} \beta$-induced microglia activation in animal models.

\section{Materials and Methods}

\subsection{Animals}

Healthy adult male Wistar rats, $180-220 \mathrm{~g}$ in weight, were obtained from the National Animal Center, Mahidol University, Thailand. All experiments were conducted under the National Guidelines of Animal Care and were approved by the Ethics Committee of Khon Kaen University (Approval No. 0514.1.12.2/64). The rats were housed at $23 \pm 2{ }^{\circ} \mathrm{C}$ under a $12 \mathrm{~h}$ light $/ 12 \mathrm{~h}$ dark cycle (lights on from 06:00 to 18:00). They were maintained in groups of four in cages with free access to food and water.

\subsection{Materials and Plant Extract Preparation}

The aged garlic extract (AGE) was provided by the Center for Research and Development of Herbal Health Products (CRD-HHP), Khon Kaen University, Thailand. AGE was prepared from fresh garlic in 30\% ethanol and fermented at room temperature for approximately 15 months under light protection. AGE used for this study contained S-allylcysteine (SAC) at $30.96 \mathrm{mg} / \mathrm{g}$ and allicin at $32 \mu \mathrm{g} / \mathrm{g}$ (Petty Patent No. 3506, Thailand). All chemicals in this study were analytical grade.

\subsection{A (1-42) Injection and Drug Treatments}

A $\beta$ (1-42) peptide (Alexis Biochemicals, San Diego, CA, USA) was dissolved in glacial acetic acid at a concentration of $1 \mu \mathrm{g} / \mu \mathrm{L}$, and the solution was incubated at $37^{\circ} \mathrm{C}$ for $24 \mathrm{~h}$ to induce peptide aggregation. The aliquots were stored at $-20{ }^{\circ} \mathrm{C}$ until the moment of use. Forty-eight rats were randomly divided into six groups $(n=8)$. Group 1 was the control group, consisting of healthy rats that did not receive any treatment. The rats in Group $2(V+A \beta)$ were fed distilled water. Those in Group 3 $($ Celeb $+\mathrm{A} \beta$ ) were fed Celebrex at $10 \mathrm{mg} / \mathrm{kg}$ BW. Finally, the rats in Groups 4, 5, and 6 (AGE125 + A $\beta$, AGE $250+A \beta$ and AGE500 + A $\beta$ ) were fed with AGE at 125, 250, and $500 \mathrm{mg} / \mathrm{kg}$ BW, respectively. The treatments were administered daily for sixty-five days. At day fifty-six, all rats in Groups 2-6 
were injected with $1 \mu \mathrm{L}$ of aggregated $\mathrm{A} \beta$ (1-42) peptide into each lateral ventricle, bilaterally at a rate of $0.2 \mu \mathrm{L} / \mathrm{min}$ [22] using the following coordinates: $\mathrm{AP}-0.8 \mathrm{~mm}$ from bregma; $\mathrm{ML} \pm 1.5 \mathrm{~mm}$ from bregma; SI $-3.8 \mathrm{~mm}$ from dura [23]. Seven days after A $\beta$ (1-42) injection, all rats were tested for novel object recognition (NOR) (Figure 1). They were then sacrificed and the density of microglia and concentration of IL- $1 \beta$ and TNF $\alpha$ in the cerebral cortex and hippocampus were determined.

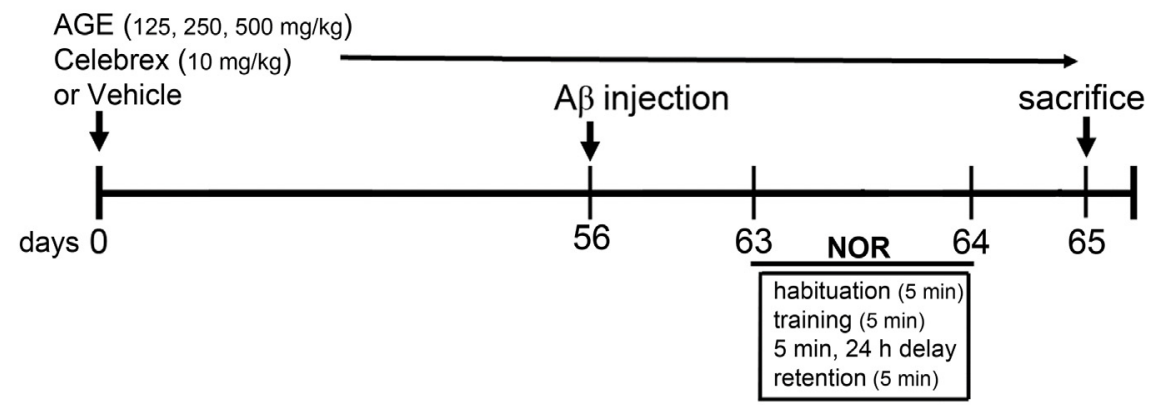

Figure 1. A schematic diagram of drug treatment and behavioral tests. Rats were injected with $\mathrm{A} \beta$ (1-42) into both sides of lateral ventricle after 56 days of drug treatments (NOR: novel object recognition, A $\beta$ : $\beta$-amyloid (1-42)).

\subsection{Novel Object Recognition (NOR)}

The NOR procedure consisted of three sessions: habituation, training, and retention. In the first session, each rat individually explored the box, which was empty of any objects, for $5 \mathrm{~min}$. During the training session, two novel objects were introduced, each placed at a different location in the box. Each rat was then allowed to explore in the box again for $5 \mathrm{~min}$. A rat was considered to be exploring an object when its head was facing the object or it was touching or sniffing the object. The time spent exploring each object was recorded. After training, the rats were immediately returned to their home cages. In the last session, one of the objects was replaced with a novel object. Twenty-four hours after the five-minute training session, each rat was again placed in the box to explore for $5 \mathrm{~min}$, and the time spent exploring each object was recorded. The box and objects were cleaned with $20 \%$ ethanol before the first trial and between trials to minimize odor cues. The ability to recognize the novel object was evaluated using a discrimination index (DI) calculated for each animal using the formula: $(\mathrm{N}-\mathrm{F} / \mathrm{N}+\mathrm{F})$ [24], which corresponds to the difference between the time exploring the novel $(\mathrm{N})$ and the familiar object $(\mathrm{F})$, corrected for total time exploring both objects. The result can vary between +1 and -1 , where a positive score indicates more time spent with the novel object, a negative score indicates more time spent with the familiar object, and a zero score indicates a null preference.

\subsection{Tissue Processing}

After the behavioral tests, the rats were anesthetized and perfused with $0.9 \%$ normal saline. Brains were immediately put on ice and cut at the midline dividing the brain into two hemispheres. The cerebral cortex and hippocampus from the right hemisphere were separated and immediately stored at $-80{ }^{\circ} \mathrm{C}$ for Western blotting analysis. The left hemisphere was cryopreserved in sucrose solution (30\%) and fixed in ice-cold $4 \%$ paraformaldehyde solution for immunohistochemical investigation of anti-integrin $\alpha \mathrm{M}(\mathrm{CD} 11 \mathrm{~b})$ using a free-floating technique. Coronal serial sections (35 $\mu \mathrm{m}$ thick) were cut with a sliding microtome and put in cold $0.01 \mathrm{M}$ phosphate buffer solution, pH 7.4 (PBS).

\subsection{Immunohistochemistry}

Coronal brain sections from each animal were incubated in blocking serum $(1 \%$ bovine serum albumin (BSA) in PBS) for $1 \mathrm{~h}$. They were incubated overnight with mouse monoclonal anti-integrin $\alpha \mathrm{M}$ (CD11b) antibody (1:100; Merck Millipore, Darmstadt, Hesse, Germany) in blocking serum. 
After rinsing, the sections were incubated with HRP-goat anti-mouse IgG secondary antibody (1:500; Invitrogen, Carlsbad, CA, USA) at room temperature for $2 \mathrm{~h}$. After washing in PBS, the sections were treated with $0.001 \%$ diaminobenzidine tetrahydrochloride dihydrate (Sigma-Aldrich, St. Louis, $\mathrm{MO}, \mathrm{USA}$ ) in PBS containing $0.003 \% \mathrm{H}_{2} \mathrm{O}_{2}$ (Merck, Darmstadt, Germany). Then the sections were mounted on gelatin-coated glass slides, allowed to dry overnight, dehydrated and cover-slipped under DPX (Sigma, St. Louis, MO, USA). Slides were viewed under a light microscope (Nikon Microscope ECLIPSE E200 MVR) with a 40× objective, and microglia positive cells were blindly counted in the hippocampus and cerebral cortex. The immunostaining was analyzed as the percentage of labeled area captured (positive pixels)/the full area captured (total pixels) using the image processing and analysis using Java software (Windows version, National Institutes of Health, Bethesda, MD, USA) [25-27].

\subsection{Western Blotting}

The brain tissue was prepared for Western blotting, as has previously been described [28]. Protein samples were resolved on $12 \%$ sodium dodecyl sulfate polyacrylamide gel electrophoresis under reducing conditions (Bio-Rad Laboratories $\mathrm{GmbH}$, Munich, Germany). They were electrophoretically transferred onto nitrocellulose membranes and blocked with 5\% non-fat dried milk (Sigma-Aldrich) in $25 \mathrm{mM}$ tris-buffered saline containing $0.1 \%$ tween 20 (TBS-T) at room temperature for $1 \mathrm{~h}$. The membranes were then probed with primary antibodies, including a rabbit polyclonal anti-IL1- $\beta$ antibody (1:500; Abcam, Milton, Cambridge, UK), a rabbit polyclonal anti-TNF $\alpha$ antibody (1:100; Abcam, Milton, Cambridge, UK) and a mouse monoclonal anti-glyceraldehyde 3 phosphate dehydrogenase (GAPDH) antibody as a reference protein (1:20,000; Abcam, Milton, Cambridge, UK) in TBS-T at $4{ }^{\circ} \mathrm{C}$ for $24 \mathrm{~h}$. After extensive washing with TBS-T, the membranes were incubated with peroxidase conjugated secondary antibody (1:1000, Merck Millipore, Billerica, MA, USA) at room temperature for $2 \mathrm{~h}$. Signals were detected by enhanced chemiluminescence (Thermo Scientific, Waltham, MA, USA) and exposed onto film. The optical density of the bands was quantified using the image processing and analysis with Java software (Windows version, National Institutes of Health, Bethesda, MD, USA).

\subsection{Statistical Analysis}

All statistical parameters were calculated using GraphPad Prism (V 5.0, GraphPad Software, La Jolla, CA, USA). All data are expressed as means \pm standard error of mean (S.E.M.). Statistical significance was determined using one-way analysis of variance (ANOVA) followed by a Newman-Keuls post-hoc test for multiple comparisons. Differences were considered significant at $p<0.05$.

\section{Results}

\subsection{Effect of AGE On Recognition Memory}

Recognition memory was evaluated by NOR at day 63 and day 64 (Figure 2). During training session, the results shows no significant difference in the time spent exploring the two identical objects, because both objects were novel (Figure 2A). In the first retention period (delay $5 \mathrm{~min}$ ), only the animals that received $A \beta$ (1-42) and AGE125 still showed deficits in short-term memory retention. In contrast, the animals given AGE at doses of 250 and $500 \mathrm{mg} / \mathrm{kg}$ BW explored the novel object significantly more than the familiar object ( $a, p<0.05$; Figure $2 \mathrm{~B}$ ), indicating recognition memory retrieval. However, in the long-term retention test (delay $24 \mathrm{~h}$ ), all doses of AGE tended to increase the discrimination index, but did not reverse the toxic effect of $A \beta(1-42)$, as observed by the fact that there were no significant differences among the groups in time spent exploring the novel object. The group that received $A \beta$ (1-42) showed significant memory deficit when compared to the control ( $a, p<0.05$; Figure 2C). 

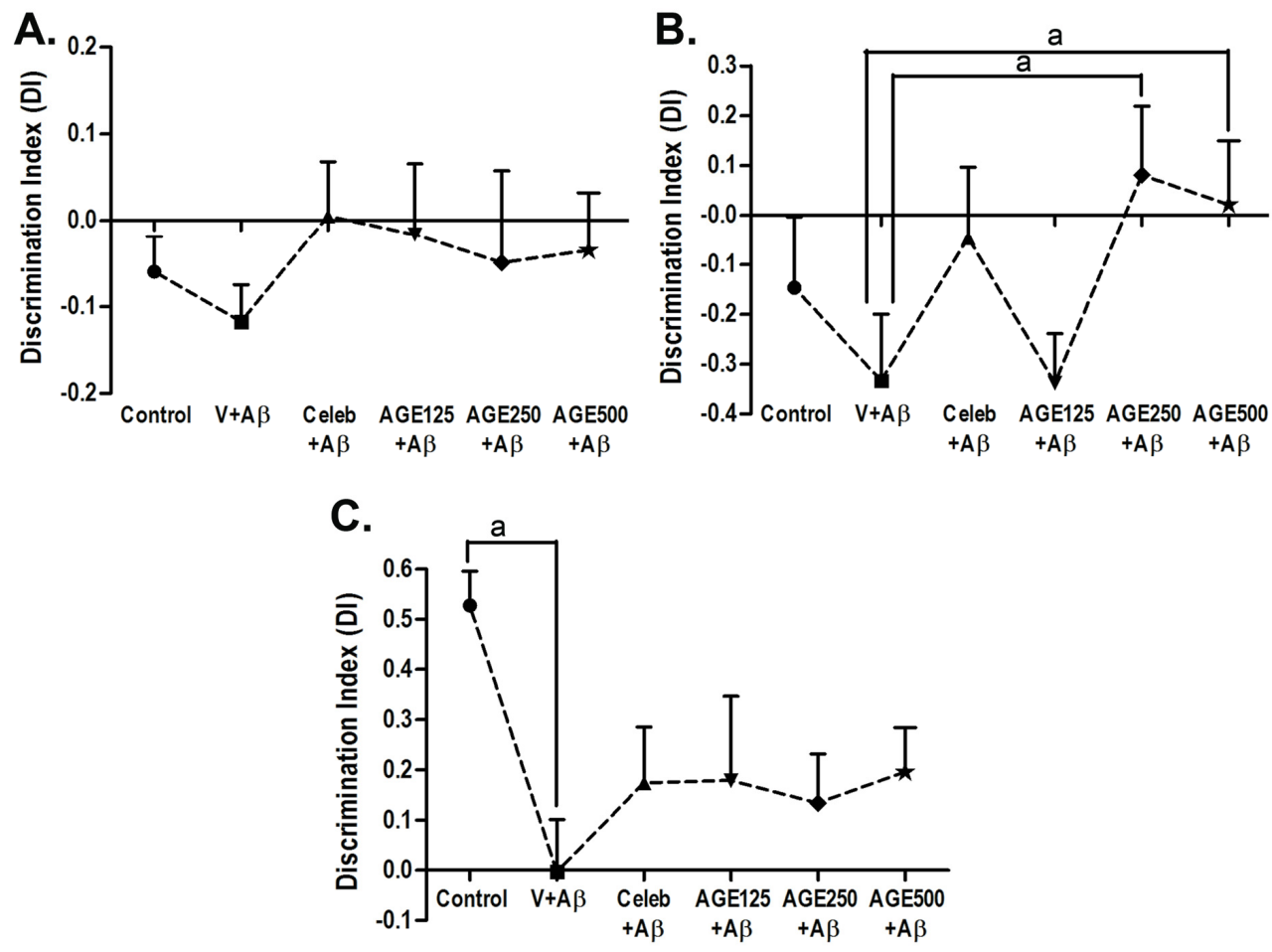

Figure 2. The discrimination index (DI) in the training phase (A); after a five-minute delay (B) and $24 \mathrm{~h}$ delay $(\mathbf{C})$ in the novel object recognition test. Data are presented as mean \pm S.E.M. (standard error of mean), $\mathrm{a}=$ significant differences from vehicle $+\mathrm{A} \beta$ group at $p<0.05$.

\subsection{Effect of AGE on Microglia Activation in the Cerebral Cortex and Hippocampus}

$\mathrm{CD} 11 \mathrm{~b}$ is a member of the integrin family that expresses on the surface of microglia. Increased expression of $\mathrm{CD} 11 \mathrm{~b}$ represents microglia activation during neurodegenerative inflammation. In this study, the determination of CD11b immunoreactivity was performed as a measure of microglia activation. Microglia in two regions of the control brain sections were generally found to have a ramified morphology (Figure 3a,g). In $A \beta$ (1-42) treated rats, the microglia showed various clusters of cells with shortened and thickened processes similar to amoeboid morphology, indicating activated microglia (Figure 3b,h). Some microglia remained ramified with small cell bodies, and some became hypertrophic with strongly stained cell bodies and thicker processes were seen in the AGE-(Figure 3d-f,j-l) and Celebrex-treated rats (Figure 3c,i). Some aggregation of microglia could also be observed in the AGE- and Celebrex-treated rats. The CD11b immunoreactivity in the cerebral cortex and hippocampus were also analyzed as percentage of labeled area. They were significantly higher in the $\mathrm{A} \beta$ (1-42)-treated groups when compared to the control group ( $a, p<0.001$; Figure 3B,D). However, the activation of microglia was significantly inhibited after $A \beta(1-42)$ injection in animals treated with Celebrex and all doses of AGE (b, $p<0.001$ and c, $p<0.01$; Figure 3B,D) in both regions of the brain, compared with those animals treated with saline. 
A.

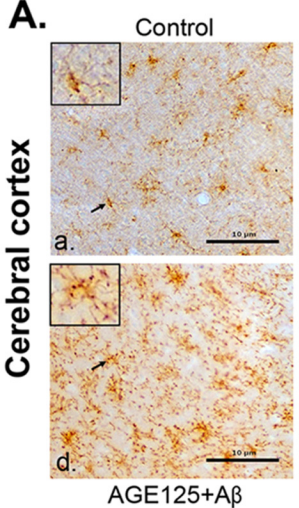

C.

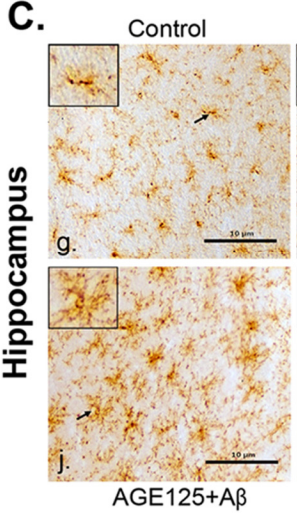

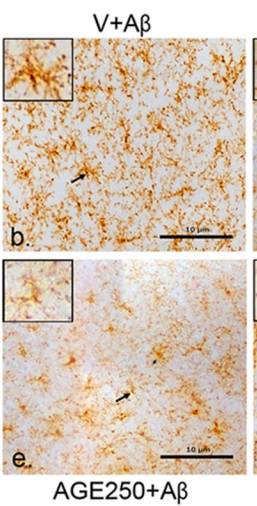

$V+A \beta$

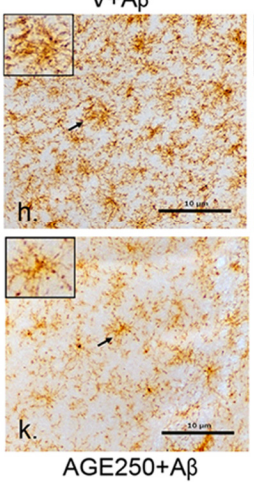

Celeb $+A \beta$

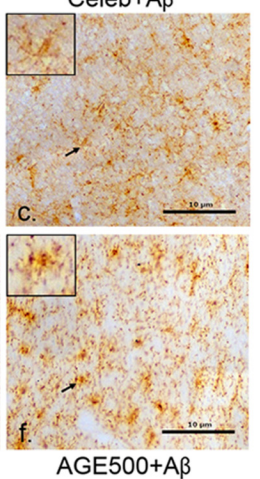

Celeb $+A \beta$

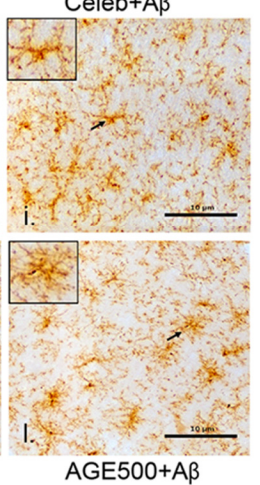

B.

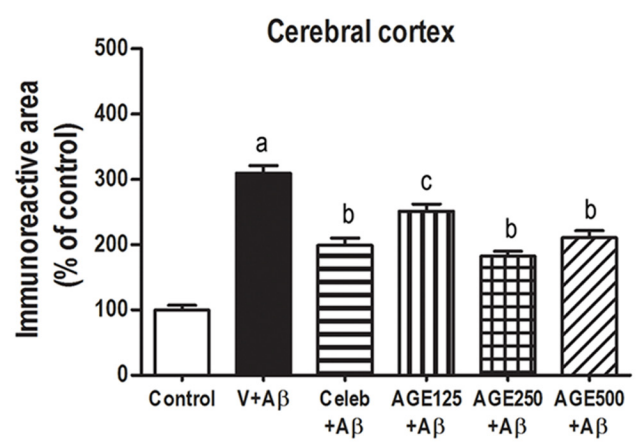

D.

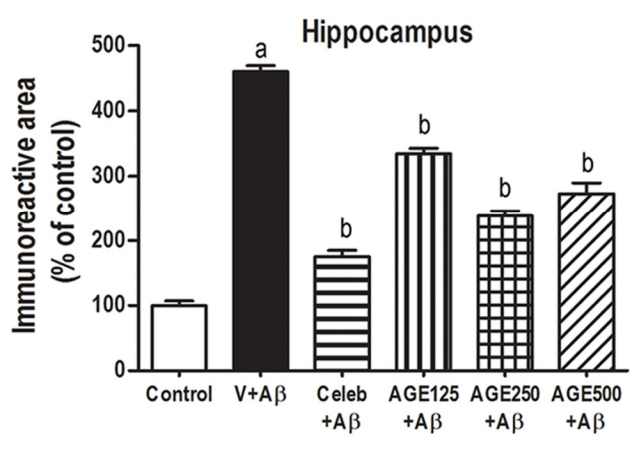

Figure 3. Effect of AGE on CD11b immunoreactivity in the cerebral cortex and hippocampus of the rat brain: $(\mathbf{A}, \mathbf{C})$ the photomicrographs of brain sections showing the distribution of microglia activating cells by immunohistochemistry staining in the cerebral cortex and hippocampus, respectively; Control $(\mathbf{a}, \mathbf{g}) ; \mathrm{V}+\mathrm{A} \beta(\mathbf{b}, \mathbf{h}) ; \mathrm{Celeb}+\mathrm{A} \beta(\mathbf{c}, \mathbf{i}) ; \mathrm{AGE} 125+\mathrm{A} \beta(\mathbf{d}, \mathbf{j}) ; \mathrm{AGE} 250+\mathrm{A} \beta(\mathbf{e}, \mathbf{k})$ and AGE500 + A $\beta(\mathbf{f}, \mathbf{l}) ;$ arrows point to examples of microglia cells in the rectangular frame; $(\mathbf{B}, \mathbf{D})$ The bar graphs represent the $\mathrm{CD} 11 \mathrm{~b}$ immunoreactive area in the cerebral cortex and hippocampal regions of the rat brain. Data are presented as mean \pm S.E.M., a $=$ significant differences from control group at $p<0.001$ and $\mathrm{b}, \mathrm{c}=$ significant differences from vehicle $+\mathrm{A} \beta$ group at $p<0.001$ and $p<0.01$, respectively.

\subsection{Effect of AGE on IL-1 $\beta$ and TNF $\alpha$ Expression in the Cerebral Cortex and Hippocampus}

Activated microglia cells are significant sources of proinflammatory cytokines and neuroinflammation. This study investigated the density of two proinflammatory cytokines, IL- $1 \beta$ and TNF $\alpha$, induced by A $\beta$ (1-42) peptides using Western blotting analysis. Treatment with A $\beta$ (1-42) significantly increased the density of IL-1 $\beta$ in the hippocampus, but not in the cerebral cortex when compared to control group (a, $p<0.001$; Figure 4A,B), whereas the density of TNF $\alpha$ in both regions of the rat brain (Figure 4C,D) did not change. The treatment of AGE at all doses markedly decreased the up-regulation of IL-1 $\beta$ in the hippocampal region of the rat brain in a similar fashion as did Celebrex (b, $p<0.001$; Figure 4B). 
A.

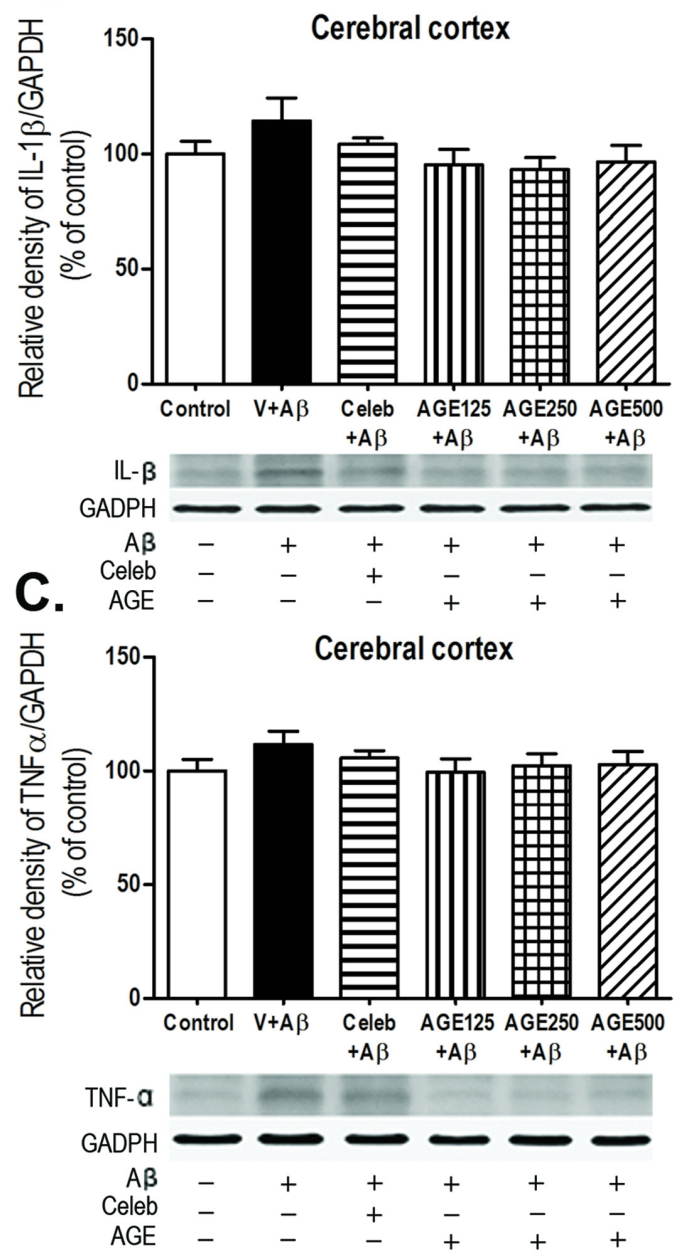

B.
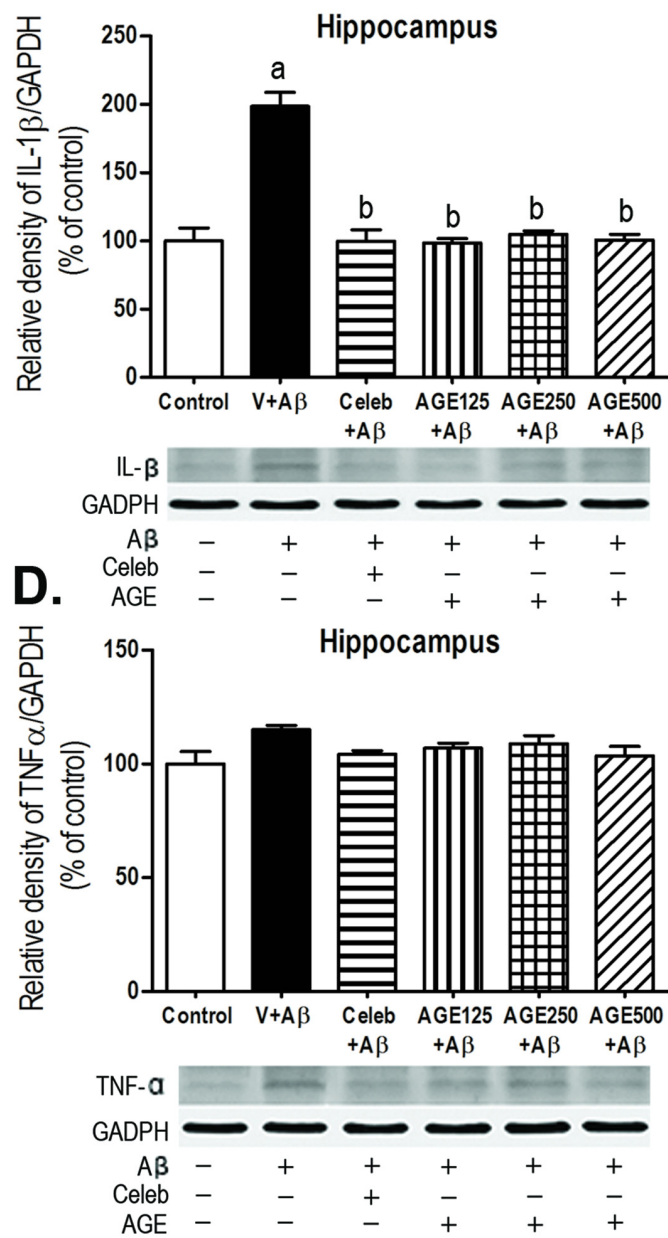

Figure 4. Effects of AGE on IL-1 $\beta(\mathbf{A}, \mathbf{B})$, and TNF $\alpha(\mathbf{C}, \mathbf{D})$ densities in the rat brain. Data are presented as mean \pm S.E.M. $\mathrm{a}=$ significant differences from control group at $p<0.001$ and $\mathrm{b}=$ significant differences from vehicle $+\mathrm{A} \beta$ group at $p<0.001$.

\section{Discussion}

Our findings revealed that pre-exposure to all doses of AGE prevented recognition memory impairment caused by A $\beta$ (1-42)-treatment. AGE at doses of 250 and $500 \mathrm{mg} / \mathrm{kg}$ BW can ameliorate cognitive impairments in short-term memory ( 5 min delay) (Figure 2B), but all doses of AGE were not able to significantly improve long-term memory in the novel object recognition test after a $24 \mathrm{~h}$ delay (Figure 2C). As previously reported, the rats generally spend more time exploring new objects than they do to familiar objects when the interval between the sample trial and the choice trial is $1 \mathrm{~h}$ or less. However, if the interval is longer, the rats cannot differentiate the familiar and new objects [29-31]. AGE pretreatment can bring back learning and recognition memory, as detected in the 5 min delay where the $A \beta$-induced rats spent more time to explore the new objects than the familiar objects. It is suggested that AGE is able to alleviate cognitive impairment involving short-term memory. However, the fact that the impairment in long-term memory is not encountered by AGE pretreatment in this study may reflect to the incomplete recovery of hippocampus injury from $A \beta$-induction. Since the delay-dependent decline in recognition memory is related to the perirhinal cortex to maintain information about the object during longer retention intervals [32,33], we observed that the injury is also confined to this region of the brain (data not shown). In addition, the intracerebroventricular (ICV) injection of $A \beta$ into the rat ventricle activated the microglia cells [34] and there is evidence to suggest that microglia activation can produce pro-inflammatory cytokines and reactive oxygen species 
(ROS) [35] causing peroxidation of membrane lipids and neuronal death [36,37] in normal aging and neurodegenerative diseases.

Moreover, stimulation of microglia can increase the $\mathrm{CD} 11 \mathrm{~b}$ expression in several neurodegenerative diseases [38]. The present data revealed that $A \beta$ (1-42) significantly increased the density of CD11b-positive microglia immunoreactivity in both the cerebral cortex and hippocampus when compared to the control. AGE at all doses $(125,250$, and $500 \mathrm{mg} / \mathrm{kg} \mathrm{BW})$ were effective against the inflammatory response induced by A $\beta$ (1-42) in that they dramatically decreased the density of CD11b-positive microglia immunoreactivity in both the cerebral cortex and hippocampus. These findings are in concordance with previous report that chronic administration of AGE and SAC can reduce the number of activated microglia surrounding $A \beta$ plaques in an Alzheimer's Swedish double mutant mouse (Tg2576) [39]. Furthermore, chronic activation of microglia can lead to an inflammatory response through the release of various proinflammatory cytokines, such as IL-1 $\beta$ and TNF $\alpha$ [40]. These cytokines are fundamental indicators of the inflammation processes [41] and overexpression of IL- $1 \beta$ surrounding A $\beta$ plaques was observed in the AD brains [42-44]. IL- $1 \beta$ has also reported to increase the production and accumulation of $A \beta$ [45-47]. This study showed that ICV injection of $A \beta$ (1-42) significantly increased the density of IL-1 $\beta$ in the hippocampus but not in the cerebral cortex. This is probably explained by the fact that the hippocampus is near to the location of the $A \beta(1-42)$ injection than cerebral cortex and, thus, $\mathrm{A} \beta$ caused more direct neurotoxicity to the hippocampus [48]. We did not find the changes in the level of another proinflamatory cytokine, TNF $\alpha$, in both the cerebral cortex and hippocampus of the brains in all studied groups. Similarly, the previous studies had shown that microglia activation did not induce TNF $\alpha$ protein level in mice with lesion-induced axonal degeneration [49] and the serum levels of TNF $\alpha$ did not change in olfactory bulbectomized-induced rats [50]. In terms of the mechanism of action, $A \beta$ interacts with several receptors on the cell surface of microglia, especially CD36. The combination of $A \beta$ with CD36 receptors, CD36 acting as a co-receptor of TLR4 and TLR6 expressed in the form of CD36-TLR4-TLR6 complex [51], stimulates the NOD-, LRR-, and pyrin domain-containing 3 (NLRP3) inflammasome to change to NLRP3 inflammasome activation signaling, inducing the release of IL- $1 \beta$ to come outside the microglia [52]. Therefore, A $\beta$ injection induced more severe inflammation in the hippocampus than in cerebral cortex, resulting in the significant release of IL- $1 \beta$ in this region of the brain. While TNF $\alpha$ were significantly produced by activation of monocytes and the severity of inflammation from $A \beta$-treatment is not enough to induce the infiltration of monocytes into brain tissue [53]. The finding on neuroprotective and anti-inflammatory effects of AGE in our studies is in concordance with several previous reports, such as AGE and SAC (a major compound from AGE) decreased the brain levels of IL-1 $\beta$ and TNF $\alpha$ in Tg2576 mice [39], SAC protected the cell death of A $\beta$ (1-40)-induced PC12 cells [54], the aqueous garlic extracts reduced the release of prionflammatory cytokine (IL-1 $\beta$ and TNF $\alpha$ ) in lipopolysaccharide-activated RAW 264.7 cells [55,56], and allicin decreased the expression of prionflammatory cytokine (IL- $1 \beta$ and $\mathrm{TNF} \alpha$ ) in the traumatic brain injury in rats [57]. In terms of phytochemical analysis of AGE, SAC was detected as the major ingredient $(30.96 \mathrm{mg} / \mathrm{g})$ with low level of allicin $(32 \mu \mathrm{g} / \mathrm{g})$ [58]. Allicin is mainly found in fresh crushed garlic, is chemically unstable, and changed to SAC during the aging processes [56,59]. Therefore, SAC may be one of the chemical contributors of AGE to confer anti-inflmmatory effects against neurotoxicity of $A \beta$ in our study. However, other compounds in AGE may also play roles and the mechanism of AGE in modulating neuroinflammaion is required to be investigated further.

In addition, several studies reported that the neuroprotective effects of natural products in $\mathrm{AD}$ models such as pretreatment of Cereboost ${ }^{\mathrm{TM}}$, an American ginseng extract, improved learning and memory-deficit by enhancing the brain acetylcholine level via ChAT gene expression in A $\beta$ (1-42)-induced mice [60], treatment of curcumin decreased the prionflammatory cytokine, IL-1 $\beta$, oxidative damage, insoluble $A \beta$, soluble $A \beta$, and $A \beta$ plaque burden in Tg2576 mice [61], and treatment of green tea reduced the cerebral A $\beta$ levels in $\mathrm{Tg} 2576$ mouse by promoting the non-amyloidogenic $\alpha$-secretase proteolytic pathway [62]. The previous data demonstrate that several natural products are 
able to protect the nervous system and AGE is one of the potential candidates to delay the progression of AD.

\section{Conclusions}

In conclusion, ICV administration of $A \beta$ (1-42) induced amnesic effects with regard to both short-term and long-term memories in rats. In addition, $A \beta(1-42)$ caused an inflammatory response by activating the microglia and increasing the density of proinflammatory cytokine, IL- $1 \beta$, in the rat brain. Pretreatment of AGE alleviated the recognition memory impairment involving short-term memory in $A \beta$ (1-42)-induced rats by decrease the density of CD11b-positive microglia immunoreactivity and the density of IL-1 $\beta$ in the injured brain. Therefore, it is suggested that AGE could be a good supplementary food for the improvement of cognitive function in the elderly and AD patients.

Acknowledgments: This study was supported by the Higher Education Research Promotion and National Research, University Project of Thailand, Office of the Higher Education Commission, through the Food and Functional Food Research Cluster of Khon Kaen University and Center for Research and Development of Herbal Health Products (CRD-HHP) under Grant M 54153, and by Faculty of Medicine, Khon Kaen University, Khon Kaen, Thailand, under Grant IN 58125. We thank Dylan Southard, Human Sciences, for assistance with the English-language presentation of the manuscript.

Author Contributions: W.P. and K.S. conceived and designed the experiments; N.N., J.U.W., W.C. and W.P. performed the experiments and analyzed the data; B.S., W.P., W.C. and J.U.W. contributed to the reagents and materials; W.P., B.S. and K.S. guided research; N.N., W.P. and B.S. drafted the manuscript; W.P. and B.S. revised the manuscript content. All authors read and approved the final manuscript.

Conflicts of Interest: The authors declare no conflict of interest.

\section{Abbreviations}

The following abbreviations are used in this manuscript:

\begin{tabular}{|c|c|}
\hline $\mathrm{A} \beta$ & $\beta$-amyloid \\
\hline $\mathrm{AD}$ & Alzheimer's disease \\
\hline AGE & Aged garlic extract \\
\hline ANOVA & analysis of variance \\
\hline AP & anterior-posterior \\
\hline BSA & bovine serum albumin \\
\hline BW & body weight \\
\hline Celeb & Celebrex \\
\hline CD11b & anti-integrin $\alpha \mathrm{M}$ \\
\hline $\mathrm{COX}-2$ & cyclooygenase-2 \\
\hline CRD-HHP & Center for Research and Development of Herbal Health Products \\
\hline DI & discrimination index \\
\hline DPX & Depex mounting medium \\
\hline $\mathrm{F}$ & familiar object \\
\hline G & Gram \\
\hline GAPDH & anti-glyceraldehyde 3 phosphate dehydrogenase \\
\hline $\mathrm{H}$ & Hour \\
\hline $\mathrm{H}_{2} \mathrm{O}_{2}$ & hydrogen peroxide \\
\hline $\mathrm{ICV}$ & Intracerebroventricular \\
\hline IL-1 $\beta$ & interleukin-1 $\beta$ \\
\hline $\mathrm{Kg}$ & Kilogram \\
\hline M & Molar \\
\hline $\mathrm{Mg}$ & Milligram \\
\hline Min & Minute \\
\hline $\mathrm{MO}$ & Missouri \\
\hline$\mu \mathrm{L}$ & Microliter \\
\hline$\mu \mathrm{m}$ & Micrometer \\
\hline ML & medial-lateral \\
\hline $\mathrm{N}$ & novel object \\
\hline NLRP3 & NOD-, LRR- and pyrin domain-containing 3 \\
\hline NOR & novel object recognition \\
\hline NSAIDs & non-steroidal anti-inflammatory drugs \\
\hline
\end{tabular}




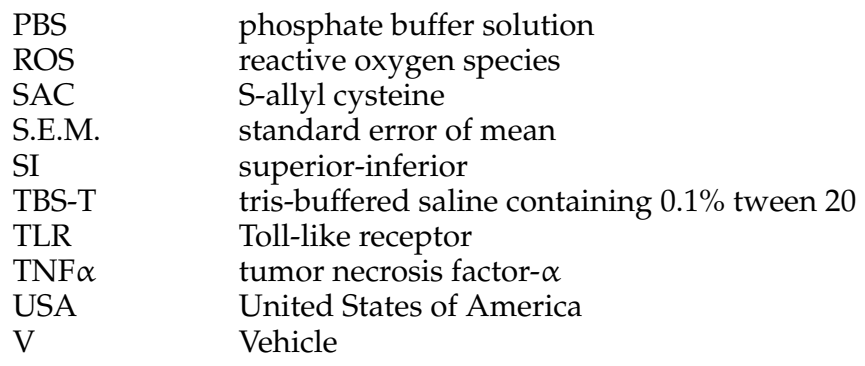

\section{References}

1. Blennow, K.; de Leon, M.J.; Zetterberg, H. Alzheimer's disease. Lancet 2006, 368, 387-403. [CrossRef]

2. Akiyama, H.; Barger, S.; Barnum, S.; Bradt, B.; Bauer, J.; Cole, G.M.; Cooper, N.R.; Eikelenboom, P.; Emmerling, M.; Fiebich, B.L.; et al. Inflammation and Alzheimer's disease. Neurobiol. Aging 2000, 21, 383-421. [CrossRef]

3. Mattson, M.P.; Maudsley, S.; Martin, B. A neural signaling triumvirate that influences ageing and age-related disease: Insulin/IGF-1, bdnf and serotonin. Ageing Res. Rev. 2004, 3, 445-464. [CrossRef] [PubMed]

4. McGeer, E.G.; McGeer, P.L. The importance of inflammatory mechanisms in Alzheimer disease. Exp. Gerontol. 1998, 33, 371-378. [CrossRef]

5. Hickman, S.E.; Allison, E.K.; El Khoury, J. Microglial dysfunction and defective beta-amyloid clearance pathways in aging Alzheimer's disease mice. J. Neurosci. 2008, 28, 8354-8360. [CrossRef] [PubMed]

6. Johnston, H.; Boutin, H.; Allan, S.M. Assessing the contribution of inflammation in models of Alzheimer's disease. Biochem. Soc. Trans. 2011, 39, 886-890. [CrossRef] [PubMed]

7. Rogers, J.; Lue, L.F. Microglial chemotaxis, activation, and phagocytosis of amyloid beta-peptide as linked phenomena in Alzheimer's disease. Neurochem. Int. 2001, 39, 333-340. [CrossRef]

8. Gonzalez-Scarano, F.; Baltuch, G. Microglia as mediators of inflammatory and degenerative diseases. Annu. Rev. Neurosci. 1999, 22, 219-240. [CrossRef] [PubMed]

9. Eikelenboom, P.; Zhan, S.S.; van Gool, W.A.; Allsop, D. Inflammatory mechanisms in Alzheimer's disease. Trends Pharmacol. Sci. 1994, 15, 447-450. [CrossRef]

10. Amagase, H.; Petesch, B.L.; Matsuura, H.; Kasuga, S.; Itakura, Y. Intake of garlic and its bioactive components. J. Nutr. 2001, 131, 955S-962S. [PubMed]

11. Chauhan, N.B. Multiplicity of garlic health effects and Alzheimer's disease. J. Nutr. Health Aging 2005, 9, 421-432. [PubMed]

12. Borek, C. The health benefits of aged garlic extract. Townsend Lett. Dr. Patients 2004, 8-9, 112-116.

13. Borek, C. Garlic reduces dementia and heart-disease risk. J. Nutr. 2006, 136 (Suppl. 3), 810S-812S. [PubMed]

14. Brown, C.; Gwebu, E.T. Effect of aged garlic extract on caspase-3 activity in PC12 cells. J. Ala. Acad. Sci. 2003, $74,132-133$.

15. Griffin, W.S.; Sheng, J.G.; Royston, M.C.; Gentleman, S.M.; McKenzie, J.E.; Graham, D.I.; Roberts, G.W.; Mrak, R.E. Glial-neuronal interactions in Alzheimer's disease: The potential role of a 'cytokine cycle' in disease progression. Brain Pathol. 1998, 8, 65-72. [CrossRef] [PubMed]

16. Jackson, R.; McNeil, B.; Taylor, C.; Holl, G.; Ruff, D.; Gwebu, E. Effect of aged garlic extract on human recombinant caspace-3 activity. J. Ala. Acad. Sci. 2003, 74, 121-122.

17. Mbyirukira, G.; Gwebu, E.T. Aged garlic extract protects serum deprived PC12 cells from apoptosis. J. Ala. Acad. Sci. 2003, 74, 127-128.

18. Numagami, Y.; Sato, S.; Ohnishi, S.T. Attenuation of rat ischemic brain damage by aged garlic extracts: A possible protecting mechanism as antioxidants. Neurochem. Int. 1996, 29, 135-143. [CrossRef]

19. Kasuga, S.; Uda, N.; Kyo, E.; Ushijima, M.; Morihara, N.; Itakura, Y. Pharmacologic activities of aged garlic extract in comparison with other garlic preparations. J. Nutr. 2001, 131, 1080S-1084S. [PubMed]

20. Nishiyama, N.; Moriguchi, T.; Saito, H. Beneficial effects of aged garlic extract on learning and memory impairment in the senescence-accelerated mouse. Exp. Gerontol. 1997, 32, 149-160. [CrossRef]

21. Moriguchi, T.; Saito, H.; Nishiyama, N. Anti-ageing effect of aged garlic extract in the inbred brain atrophy mouse model. Clin. Exp. Pharmacol. Physiol. 1997, 24, 235-242. [CrossRef] [PubMed] 
22. Chen, X.; Hu, J.; Jiang, L.; Xu, S.; Zheng, B.; Wang, C.; Zhang, J.; Wei, X.; Chang, L.; Wang, Q. Brilliant blue g improves cognition in an animal model of Alzheimer's disease and inhibits amyloid-beta-induced loss of filopodia and dendrite spines in hippocampal neurons. Neuroscience 2014, 279, 94-101. [CrossRef] [PubMed]

23. Lin, H.B.; Yang, X.M.; Li, T.J.; Cheng, Y.F.; Zhang, H.T.; Xu, J.P. Memory deficits and neurochemical changes induced by C-reactive protein in rats: Implication in Alzheimer's disease. Psychopharmacology 2009, 204, 705-714. [CrossRef] [PubMed]

24. Antunes, M.; Biala, G. The novel object recognition memory: Neurobiology, test procedure, and its modifications. Cogn. Process. 2012, 13, 93-110. [CrossRef] [PubMed]

25. Medeiros, R.; Kitazawa, M.; Passos, G.F.; Baglietto-Vargas, D.; Cheng, D.; Cribbs, D.H.; LaFerla, F.M. Aspirin-triggered lipoxin A4 stimulates alternative activation of microglia and reduces Alzheimer disease-like pathology in mice. Am. J. Pathol. 2013, 182, 1780-1789. [CrossRef] [PubMed]

26. Passos, G.F.; Medeiros, R.; Cheng, D.; Vasilevko, V.; Laferla, F.M.; Cribbs, D.H. The bradykinin B1 receptor regulates abeta deposition and neuroinflammation in Tg-SwDI mice. Am. J. Pathol. 2013, 182, 1740-1749. [CrossRef] [PubMed]

27. Town, T.; Laouar, Y.; Pittenger, C.; Mori, T.; Szekely, C.A.; Tan, J.; Duman, R.S.; Flavell, R.A. Blocking TGF-beta-Smad2/3 innate immune signaling mitigates Alzheimer-like pathology. Nat. Med. 2008, 14, 681-687. [PubMed]

28. Mustafa, S.; Walker, A.; Bennett, G.; Wigmore, P.M. 5-fluorouracil chemotherapy affects spatial working memory and newborn neurons in the adult rat hippocampus. Eur. J. Neurosci. 2008, 28, 323-330. [CrossRef] [PubMed]

29. Deschaux, O.; Bizot, J.C.; Goyffon, M. Apamin improves learning in an object recognition task in rats. Neurosci. Lett. 1997, 222, 159-162. [CrossRef]

30. Ennaceur, A.; Meliani, K. A new one-trial test for neurobiological studies of memory in rats. III. Spatial vs. Non-spatial working memory. Behav. Brain Res. 1992, 51, 83-92. [CrossRef]

31. Puma, C.; Bizot, J.C. Intraseptal infusions of a low dose of AP5, a NMDA receptor antagonist, improves memory in an object recognition task in rats. Neurosci. Lett. 1998, 248, 183-186. [CrossRef]

32. Murray, E.A.; Richmond, B.J. Role of perirhinal cortex in object perception, memory, and associations. Curr. Opin. Neurobiol. 2001, 11, 188-193. [CrossRef]

33. Reger, M.L.; Hovda, D.A.; Giza, C.C. Ontogeny of rat recognition memory measured by the novel object recognition task. Dev. Psychobiol. 2009, 51, 672-678. [CrossRef] [PubMed]

34. Takata, K.; Kitamura, Y.; Tsuchiya, D.; Kawasaki, T.; Taniguchi, T.; Shimohama, S. Heat shock protein-90-induced microglial clearance of exogenous amyloid-beta1-42 in rat hippocampus in vivo. Neurosci. Lett. 2003, 344, 87-90. [CrossRef]

35. Meda, L.; Cassatella, M.A.; Szendrei, G.I.; Otvos, L., Jr.; Baron, P.; Villalba, M.; Ferrari, D.; Rossi, F. Activation of microglial cells by beta-amyloid protein and interferon-gamma. Nature 1995, 374, 647-650. [CrossRef] [PubMed]

36. Valencia, A.; Moran, J. Reactive oxygen species induce different cell death mechanisms in cultured neurons. Free Radic. Biol. Med. 2004, 36, 1112-1125. [CrossRef] [PubMed]

37. Choi, S.J.; Kim, M.J.; Jin Heo, H.; Kim, J.K.; Jin Jun, W.; Kim, H.K.; Kim, E.K.; Ok Kim, M.; Yon Cho, H.; Hwang, H.J.; et al. Ameliorative effect of 1,2-benzenedicarboxylic acid dinonyl ester against amyloid beta peptide-induced neurotoxicity. Amyloid 2009, 16, 15-24. [CrossRef] [PubMed]

38. Roy, A.; Jana, A.; Yatish, K.; Freidt, M.B.; Fung, Y.K.; Martinson, J.A.; Pahan, K. Reactive oxygen species up-regulate $\mathrm{CD} 11 \mathrm{~b}$ in microglia via nitric oxide: Implications for neurodegenerative diseases. Free Radic. Biol. Med. 2008, 45, 686-699. [CrossRef] [PubMed]

39. Chauhan, N.B. Effect of aged garlic extract on APP processing and tau phosphorylation in Alzheimer's transgenic model Tg2576. J. Ethnopharmacol. 2006, 108, 385-394. [CrossRef] [PubMed]

40. Hoozemans, J.J.; Rozemuller, A.J.; van Haastert, E.S.; Eikelenboom, P.; van Gool, W.A. Neuroinflammation in Alzheimer's disease wanes with age. J. Neuroinflamm. 2011, 8, 171. [CrossRef] [PubMed]

41. Latta, C.H.; Brothers, H.M.; Wilcock, D.M. Neuroinflammation in Alzheimer's disease; a source of heterogeneity and target for personalized therapy. Neuroscience 2015, 302, 103-111. [CrossRef] [PubMed]

42. Griffin, W.S.; Stanley, L.C.; Ling, C.; White, L.; MacLeod, V.; Perrot, L.J.; White, C.L., 3rd; Araoz, C. Brain interleukin 1 and S-100 immunoreactivity are elevated in down syndrome and Alzheimer disease. Proc. Natl. Acad. Sci. USA 1989, 86, 7611-7615. [CrossRef] [PubMed] 
43. Griffin, W.S.; Sheng, J.G.; Roberts, G.W.; Mrak, R.E. Interleukin-1 expression in different plaque types in Alzheimer's disease: Significance in plaque evolution. J. Neuropathol. Exp. Neurol. 1995, 54, $276-281$. [CrossRef] [PubMed]

44. Sheng, J.G.; Mrak, R.E.; Griffin, W.S. Glial-neuronal interactions in alzheimer disease: Progressive association of IL-1alpha+ microglia and S100beta+ astrocytes with neurofibrillary tangle stages. J. Neuropathol. Exp. Neurol. 1997, 56, 285-290. [CrossRef] [PubMed]

45. Grilli, M.; Goffi, F.; Memo, M.; Spano, P. Interleukin-1beta and glutamate activate the NF-kappaB/Rel binding site from the regulatory region of the amyloid precursor protein gene in primary neuronal cultures. J. Biol. Chem. 1996, 271, 15002-15007. [PubMed]

46. Yang, Y.; Quitschke, W.W.; Brewer, G.J. Upregulation of amyloid precursor protein gene promoter in rat primary hippocampal neurons by phorbol ester, IL-1 and retinoic acid, but not by reactive oxygen species. Brain Res. Mol. Brain Res. 1998, 60, 40-49. [CrossRef]

47. Rogers, J.T.; Leiter, L.M.; McPhee, J.; Cahill, C.M.; Zhan, S.S.; Potter, H.; Nilsson, L.N. Translation of the alzheimer amyloid precursor protein mRNA is up-regulated by interleukin- 1 through $5^{\prime}$-untranslated region sequences. J. Biol. Chem. 1999, 274, 6421-6431. [CrossRef] [PubMed]

48. Sanz, J.M.; Chiozzi, P.; Ferrari, D.; Colaianna, M.; Idzko, M.; Falzoni, S.; Fellin, R.; Trabace, L.; Di Virgilio, F. Activation of microglia by amyloid $\beta$ requires P2X7 receptor expression. J. Immunol. 2009, 182, 4378-4385. [CrossRef] [PubMed]

49. Fenger, C.; Drojdahl, N.; Wirenfeldt, M.; Sylvest, L.; Jorgensen, O.S.; Meldgaard, M.; Lambertsen, K.L.; Finsen, B. Tumor necrosis factor and its p55 and p75 receptors are not required for axonal lesion-induced microgliosis in mouse fascia dentata. Glia 2006, 54, 591-605. [CrossRef] [PubMed]

50. Borre, Y.; Lemstra, S.; Westphal, K.G.; Morgan, M.E.; Olivier, B.; Oosting, R.S. Celecoxib delays cognitive decline in an animal model of neurodegeneration. Behav. Brain Res. 2012, 234, 285-291. [CrossRef] [PubMed]

51. Stewart, C.R.; Stuart, L.M.; Wilkinson, K.; van Gils, J.M.; Deng, J.; Halle, A.; Rayner, K.J.; Boyer, L.; Zhong, R.; Frazier, W.A. CD36 ligands promote sterile inflammation through assembly of a toll-like receptor 4 and 6 heterodimer. Nat. Immunol. 2010, 11, 155-161. [CrossRef] [PubMed]

52. Doens, D.; Fernández, P.L. Microglia receptors and their implications in the response to amyloid $\beta$ for Alzheimer's disease pathogenesis. J. Neuroinflamm. 2014, 11, 48. [CrossRef] [PubMed]

53. Jeong, H.-K.; Ji, K.; Min, K.; Joe, E.-H. Brain inflammation and microglia: Facts and misconceptions. Exp. Neurobiol. 2013, 22, 59-67. [CrossRef] [PubMed]

54. Ito, Y.; Kosuge, Y.; Sakikubo, T.; Horie, K.; Ishikawa, N.; Obokata, N.; Yokoyama, E.; Yamashina, K.; Yamamoto, M.; Saito, H. Protective effect of S-allyl-L-cysteine, a garlic compound, on amyloid $\beta$-protein-induced cell death in nerve growth factor-differentiated PC12 cells. Neurosci. Res. 2003, 46, 119-125. [CrossRef]

55. Jeong, Y.Y.; Ryu, J.H.; Shin, J.-H.; Kang, M.J.; Kang, J.R.; Han, J.; Kang, D. Comparison of anti-oxidant and anti-inflammatory effects between fresh and aged black garlic extracts. Molecules 2016, 21, 430. [CrossRef] [PubMed]

56. Shin, J.-H.; Ryu, J.H.; Kang, M.J.; Hwang, C.R.; Han, J.; Kang, D. Short-term heating reduces the anti-inflammatory effects of fresh raw garlic extracts on the LPS-induced production of NO and pro-inflammatory cytokines by downregulating allicin activity in raw 264.7 macrophages. Food Chem. Toxicol. 2013, 58, 545-551. [CrossRef] [PubMed]

57. Chen, W.; Qi, J.; Feng, F.; Wang, M.D.; Bao, G.; Wang, T.; Xiang, M.; Xie, W.F. Neuroprotective effect of allicin against traumatic brain injury via Akt/endothelial nitric oxide synthase pathway-mediated anti-inflammatory and anti-oxidative activities. Neurochem. Int. 2014, 68, 28-37. [CrossRef] [PubMed]

58. Saenthaweesuk, S. Effect of Substituting Garlic Herbal Powder for Antibiotic Growth Promoters in Ration on Growth Performance, Carcass Characteristic, Meat Quality, Blood Chemistry, Plasma Lipids and Antioxidising Response of Broilers. Ph.D. Thesis, Khon-Kaen University, Khon-Kaen, Thailand, 2006.

59. Gu, X.; Wu, H.; Fu, P. Allicin attenuates inflammation and suppresses HLA-B27 protein expression in ankylosing spondylitis mice. BioMed Res. Int. 2013, 2013, 171573. [CrossRef] [PubMed]

60. Shin, K.; Guo, H.; Cha, Y.; Ban, Y.H.; Seo da, W.; Choi, Y.; Kim, T.S.; Lee, S.P.; Kim, J.C.; Choi, E.K.; et al. Cereboost, an american ginseng extract, improves cognitive function via up-regulation of choline acetyltransferase expression and neuroprotection. Regul. Toxicol. Pharmacol. 2016, 78, 53-58. [CrossRef] [PubMed] 
61. Lim, G.P.; Chu, T.; Yang, F.; Beech, W.; Frautschy, S.A.; Cole, G.M. The curry spice curcumin reduces oxidative damage and amyloid pathology in an Alzheimer transgenic mouse. J. Neurosci. 2001, 21, 8370-8377. [PubMed]

62. Rezai-Zadeh, K.; Shytle, D.; Sun, N.; Mori, T.; Hou, H.; Jeanniton, D.; Ehrhart, J.; Townsend, K.; Zeng, J.; Morgan, D. Green tea epigallocatechin-3-gallate (EGCG) modulates amyloid precursor protein cleavage and reduces cerebral amyloidosis in Alzheimer transgenic mice. J. Neurosci. 2005, 25, 8807-8814. [CrossRef] [PubMed]

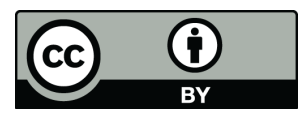

(C) 2017 by the authors; licensee MDPI, Basel, Switzerland. This article is an open access article distributed under the terms and conditions of the Creative Commons Attribution (CC-BY) license (http://creativecommons.org/licenses/by/4.0/). 